\title{
'To Study the solid waste generated per bed per day at district hospital kargil a remote high altitude area'
}

\author{
Hasina Quari ${ }^{1}$, Shah Naveed ${ }^{2}$, Maha Para $^{3}$, AsmaAltaf $^{4}$, Riyaz A Rangrez $^{5}$, \\ Rihana $^{6}$ \\ 1Postgraduate scholar S.K.I.M.S SouraKashmir, 190001 India \\ 2 Department of Surgery, ASCOMS \& Hospitals, Sidhra, Jammu, Jammu \& Kashmir, 180017, India \\ 3 Department of Dental surgery, GMC \& Hospitals, Srinagar Jammu \& Kashmir, 190007, India \\ 4 Department of Dental Surgery, ITS college \& Hospitals, gaziabad U.P. \\ 5 H.O.D Hospital administration, S.K.I.M.S Soura, Kashmir, 190001, India \\ ${ }^{6}$ Senior Resident Hospital administration S.K.I.M.S Soura Kashmir, 190001, India
}

\begin{abstract}
:
Objective:

1) To study the solid waste generated per bed per day at District hospital Kargil.

2) To study the existing system of solid waste segregation, collection, transport, storage and disposal at District hospital Kargil.
\end{abstract}

Material and Methods: The prospective study was done over a period of three months, w.e.f. $1^{\text {st }}$ August to $30^{\text {th }}$ October, 2012. During the study of 3 months, 20 days were selected randomly.In order to elicit the data for the first objective that is 'To Study the solid waste generated per bed per day at district hospital kargil', the following materials and methods were.

1) Observational Study

2) Interviews

The data about second objective i.e. To study the existing system of solid waste segregation, collection, transport, storage and disposal at district hospital kargil, the following materials and methods were used.

1) Interview

2) Personnel Observation

Results:

1) The quantum of waste generated in district hospital kargil is $2.0 \mathrm{~kg}$ per bed per day.

2) The total quantity of solid waste from the inpatients area (wards), Accident and emergency, operation theatres, outpatients department (OPD) and support services is found to be $5600 \mathrm{~kg}$ for 20 days.

3) $71 \%$ of solid waste was generated from in patient area.

KEYWORDS: biomedical waste, segregation, collection, transportation, storage, disposal

\section{INTRODUCTION}

The hospital waste can be classified into three groups. The first group comprises of mainly solid waste, and the second group mainly liquid waste ${ }^{1}$. Waste covered under Group-I Includes Dry Garbage, Wet Garbage ,Wet tissues andbones,Plaster casts ,Packing materials, Surgical Waste , Metal Waste , Glass, Disposal Plastic Items. The Group-II of hospital waste covers sewage that emanates from bathrooms lavatories toilets, kitchen, pantries, operation theatres, dressing rooms, laboratories and laundries. To this must be added the waste from radiology department comprising of chemical developer and fixer solutions. The Group-III of hospital waste is the radioactive waste from radiotherapy and nuclear medicine department, usually in large teaching hospitals.

Hospital waste generated from different units of hospital may cause serious health hazards like spread of HIV infection and Hepatitis- $\mathrm{B}^{2}$. The health risk is extended beyond the presmises of hospital, to both personnel providing support services to the hospital and to the common masses, which are extensively exposed to unprofessionally handled biomedical waste. Hospitals and other health care institutions generate waste, on continuous basis. It may prove to be a possible health hazard to the health care workers, the general public plus the flora and fauna of that area. The term waste management is used rather than disposal because the waste management to be efficient, the waste should be managed at every step of the process of acquisition of materials that eventually become waste, waste generation, discards collection, containment, accumulation, storage, transportation, treatment and disposa ${ }^{3,4}$. It is recommended to introduce following container in each ward, lab., etc., for segregation solid waste at the source of generation ${ }^{3,4,5}$. (refer to table I) 
TABLE I

\begin{tabular}{|c|c|c|c|}
\hline S.NO & CATEGORY & TYPE & WASTE CATEGORY \\
\hline 1. & Green Container & Covered & $\begin{array}{l}\text { (A) } \\
\text { General Waste (food waste, kitchen waste } \\
\text { i.e.; putrescible part) }\end{array}$ \\
\hline 2. & Red Container & Covered & $\begin{array}{l}\text { (B) } \\
\text { Microbiological, surgical, human } \\
\text { anatomical tissue, organ, blood and body } \\
\text { fluids etc., pathological, infectious waste } \\
\text { contaminated with blood secretions etc., } \\
\text { soiled cotton, dressing, beddings, animal } \\
\text { waste, research laboratory waste } \\
\text { etc., (incinerable). } \\
\text { I(C) }\end{array}$ \\
\hline 3. & Yellow Container & Covered & $\begin{array}{l}\text { Disposables, plastics, PVC, polythene, } \\
\text { sharps, e.g. needles, blades scalpels etc; } \\
\text { cardboard, thermocol discarded glasses. }\end{array}$ \\
\hline
\end{tabular}

Therefore this study is based on the need to:-

* Generate Quantitative and qualitative scientific data regarding various components of hospital solid waste, and its management.

* Improve the existing system of solid waste management at district hospital kargil.

\section{MATERIAL AND METHODS}

Solid waste management study was conducted at District hospital Kargil. Study was done to assess the quantity of waste generated and overall sequential methods till final disposal of the waste.

\section{Objective 1}

The prospective study was done over a period of three months, w.e.f. $1^{\text {st }}$ August to $30^{\text {th }}$ October, 2012. During the study of 3 months, 20 days were selected randomly.In order to elicit the data for the first objective that is

'To Study the solid waste generated per bed per day at district hospital kargil', the following materials and methods were.

1) Observational Study: The total number of containers available in the hospital were calculated which were 70 in number. The waste containers were emptied twice daily, once in morning and once in evening in the hospital waste carrying tipper. Average quantity of waste per container per day was observed to be $4 \mathrm{~kg}$. Thus the total waste generated per day was calculated.

2) Interviews :An interview was conducted with the nursing supervisor, sanitary inspector, ward incharge, OPD incharge and housekeeping staff to elicit information regarding the quantity of waste generated.

\section{Objective 2}

The data about second objective i.e. To study the existing system of solid waste segregation, collection, transport, storage and disposal at district hospital kargil, the following materials and methods were used.

(1) Interview

The interview put to the nursing supervisor, sanitary inspector, ward incharge, OPD incharge and sanitary staff helped in assessing the following:

(a) Mode of segregation, collection, transportation, storage and further to final disposal site.

(2) Personnel Observation:

It helped in confirming the data which was collected through interview.

\section{OBSERVATIONS AND DISCUSSION}

A study entitled 'Solid Waste Management' was conducted at District Hospital Kargil. District Hospital Kargil is situated in district kargil of ladakh region. A district nested in Himalayas having a population of 1.40 lakh. District hospital kargil is the main referral center from the subcenters, subdistrict hospitals, as the only road which connects the region to rest of the country remains closed for 6 months owing to heavy snowfall.District hospital kargil has a bed strength of 140 and generates $280 \mathrm{~kg}$ of solid waste per day.

\section{Sanitation Services in District Hospital Kargil}

The district hospital kargil does not have a proper sanitation department but the sanitary services are under the charge of sanitary inapector. There are a total of 20 sanitary workers and 14 among them are permanent and 6 are working on contract basis. The sanitary workers perform the job of segregating, collecting, transport and disposal of solid waste. 
The hospital is provided with 70 containers with polythene bags.. Risk to the sanitary staff from exposure to biomedical waste is prevent by following certain preventive measures such as use of gloves and masks. The colour coding of containers is used but biohazardous symbols are not used. The quantum of waste generated in district hospital kargil is $2.0 \mathrm{~kg}$ per bed per day. This is identical to studies conducted by various workers who have assessed the average quantity of hospital waste produced in India ranges from 1.5 to $2.2 \mathrm{~kg}$ per bed per day. Also a study conducted at AIIMS, New Delhi (a tertiary care hospital), in 1988 revealed the quantum of waste generated as $2.2 \mathrm{kgs}$ per patient per day.

\section{Observation of Objective No.1}

During the study of three months, 20 days were selected randomly. The total quantity of solid waste from the inpatients area (wards). Accident and emergency, operation theatres, outpatients department (OPD) and support services is found to be $5600 \mathrm{~kg}$ for 20 days, selected randomly. The amount of waste generated per bed per day is $2.0 \mathrm{~kg}$.

\section{Areawise Quantity and Percentage of Solid waste Generated, at District Hospital Kargil}

\begin{tabular}{|l|l|l|l|}
\hline S.NO & AREA & $\begin{array}{l}\text { QUANTITY } \\
(\mathrm{kgs})\end{array}$ & $\begin{array}{l}\text { PERCENTAGE } \\
(\%)\end{array}$ \\
\hline 01 & Inpatient & 2982 & 71 \\
02 & OPD & 147 & 3.5 \\
03 & Operation Theaters & 147 & 3.5 \\
04 & Accident and Emergency & 273 & 6.5 \\
& Labs. & & \\
05 & Kitchen & 168 & 4.0 \\
06 & Pharmacy & 357 & 8.5 \\
07 & & 126 & 3.0 \\
\hline
\end{tabular}

The same kind of study titled 'Study Of Bio-medical Waste Management' in teaching hospitals of Kashmir was conducted by Dr. NazirAhmad Pandit, in 1999 to 2002. The aforementioned study was done for a period of three months, 20 days were selected randomly during the study period of three month. The total solid waste generated from the Inpatients area (wards), Accident and emergency, operation theatres, outpatients Department (OPD) and support services is found to be $24357 \mathrm{~kg}$ for 20 days randomly selected during the study period of three months. The amount of waste generated per bed per day was $2.02 \mathrm{kgs}$.

In our study $71 \%$ of solid waste was generated from in patient area which is in accordance to the study conducted by Dr. Nazir Ahmad Pandit, in 1999 to 2002 in study titled 'Study Of Bio-medical Waste Management' in teaching hospitals of Kashmir Out of this quantum $(71.6 \%)$ of solid waste generated from inpatients area, $776 \mathrm{~kg}(31.8 \%)$ is generated from OPD, $714 \mathrm{~kg}(2.93 \%)$ generated from operation theatre, 1644 $\mathrm{kg}(6.74 \%)$ from accident and emergency area, $907 \mathrm{~kg}$ (3.72\%) from laboratories, $2019 \mathrm{~kg}(8.28 \%)$ from kitchen, $110 \mathrm{~kg}(0.45 \%)$ from CSSD and $724 \mathrm{~kg}(2.97 \%)$ from pharmacy Total Waste from support service area is $3760 \mathrm{~kg}(15.43 \%)$

The average quantity of biomedical waste generated is $17.22 \%$ of the total waste.

It has been observed that in developed countries, due to the advent of increased use of disposables, the waste generated is upto $5.24 \mathrm{kgs}$ per bed per day.

From available data, it can be presumed that in most hospitals in India including Kashmir, hospitals generated 1-2 kg per bed per day, except the tertiary care hospital viz AIIMS and SKIMS, which produce waste on higher scale. Use of more number of disposable items in the tertiary care hospitals can be attributed to the increased quantum of waste generated ${ }^{6}$.

The development of infectious waste regulations at the federal and state level was accompanied by proliferation of the terms used to describe this type of waste, with no uniform terminology being adopted. These terms include 'infections', infective', 'red bag', 'medical', 'biomedical', biological', 'biohazardous',

Infectious waste has not been described uniformly by federal agencies. The centers for disease control and prevention (CDC) listed type "infective waste', those are relevant to patients with acquired immunodeficiency disease virus and Hepatitis-B virus to health care and public safety workers ${ }^{7}$ The US occupational safety and health administration (OSHA) blood borne pathogens standard is called 'regulated waste $^{8}$ 
The EPA medical waste tracking regulations referred to 'regulated medical waste' where as the EPA hospital/medical/infectious waste incinerator regulations refer to medical/ infections waste to 'hospital waste" . Hospitals have been observing precautions for patients with either suspected or known infectious diseases. The CDC Hospital infection Control Practices Advisory Committee (HICPAC) have published various guidelines on isolation precautions for hospital ${ }^{7}$. EPA has taken more rigid stand than CDC on the classification of waste patients in isolation precautions.

Isolation wastes have been classified as regulated medical waste under the EPA medical waste tracking regulations and as medical/infections under EPA's hospital/medical/infectious waste incinerator regulations ${ }^{13}$. This category refers specifically to waste from patients with highly contagiously communicable diseases such as caused by certain etiological agents (for example Lassa, Marburg and Ebola virus). The advert of disposables in hospital usage has along with its many advantage also brought a few problems, for example, inappropriate recycling, disposables etc. The disposables have also quantitably increased the hospital waste. New methods of treatment and new procedures coupled with radical changes in the socio-economic trends have made many traditional medical waste management methods obsolete ${ }^{27}$.

During the last decade public concern regarding disposal of medical waste had increased considerably, fuelled by reports of 'beach waste-ups, of Florida, USA, the west coast, and the gulf coast in the summer of 1988, which raised a public outcry and was investigated by the Environmental protection agency of USA ${ }^{13}$.

Infections are the most common health associated with poor hospital waste management, which has been magnified with the advent of AIDS and hepatitis B virus infection and increase in prevalence of these diseases in health care workers working in hospitals ${ }^{3}$. Studies in USA reveal that all workers who come in contact with medical waste, those in sanitary services report highest on the job injuries ${ }^{8,9}$.

After the medical waste is generated, but before it is treated, it must be segregated, packed, stored, labeled, marked (if biohazardous) and transported. The regulations established by EPA on March $\mathbf{2 4}^{\text {th }}, \mathbf{1 9 8 9}$ refer to these activities as handling ${ }^{13}$.

According to the Sulabh institute of health and hygiene team of study, the three container segregation should be introduced in India for a beginning ${ }^{26}$. At present, no segregation of solid waste is carried out at source. As per the biomedical waste (Handling and Management) Rules 1995, biomedical waste is subject to storage. It is an important aspect of hospital waste management because improper storage may lead to the change of rag pickers and other unscrupulous elements gaining access to the stored waste and coming problem.

According to biomedical waste (management and handling) rules 1997, treatment means, "a method, technique of any process" designed to change the physical, chemical, biological characteristic or composition of any biomedical waste so as to render such waste non-hazardous to health and environment.

Investigations of medical waste practices used by hospitals in Oregon, Washington and Idaho, which includes the majority of hospitals in the US Environment Protection Agency's (EPA) region 10, was done?. During the fall of 1993,225 hospitals were surveyed with a response rate of $72.5 \%$. The results implied that the most frequently used practice of treating and disposing off of medical waste was the use of private handlers. The more frequently reported treatment techniques were pouring into the municipal sewage $46.6 \%$ disposing in landfills $41.6 \%$ and autoclaving $32.3 \%$ other method included, electro thermal deactivation (ETD). Micro waving and grinding before pouring into municipal sewar. No hospital in any of the states reported using irradiation as treatment technique. Hospitals in Oregon and Washington no longer use incinerator, whereas in other states incinerators are operated.

Used sharp instruments for disposal (for example syringes, needles and scalped blades) must be disposed off in containers confirming to approved standards (DHSS, 1982, Health Service Advisory Committee 1982), containers should be under secure conditions to prevent any unauthorized access (syringes and needles are attractions to children and drug addicts,) final disposal should be by incineration ${ }^{4,10,17}$.

A number of studies all over the world have proved that sharps need maximum precaution while handling. Almost $85 \%$ of sharps injuries are caused between their usage and subsequent disposal; and more than $20 \%$ of those who handle them encounter 'Stick' injuries 11,12,13,14,15,16,18.

Our study was done to ascertain the relevance of our socio-economic background to present practice of bio-medical waste management at district hospital kargil, a hospital located in rough terrain of ladakh region were solid waste generated per bed per day is $2.0 \mathrm{~kg}$. 
The constituent of waste are general waste, paper, solid dressings, sponges waste, ampoules, needles, syringes, disposable gloves and masks, cartons, packing materials, pharmaceutical bottles, waste from public and patients rooms, waste food from kitchen and patient care area, waste from X-ray department, sweepings from hospital and waste from pharmacy.

Segregation of the above mentioned types of waste is practiced. The waste from laboratory, sharp wastes from blue containers, placenta and blood clots from labour room are dumped in three separate pits located in the backyard of the hospital.

Solid waste from wards, OPD, pharmacy, operation theatre, I.C.U., N.I.C.U, is collected manually twice daily, in morning and evening and emptied in hospital waste carrying tipper which is positioned within the hospital premises, stored there for 4 to 5 days in the tipper only and when it is filled upto brim it is transported to kurbuthang, a place located $5 \mathrm{kms}$ away from the main town. The tipper is unloaded by the sanitary staff in a trench. The waste is burned in open with kerosene and covered with soil. Another trench is dug as soon as this fills out.

Comparative study of the waste generated from OPD, inpatients, laboratories, operation theatre and support services areas revealed that major proportion of waste is generated from the inpatient area which is upto the extent of $71 \%$ of the total quantum waste.

The sanitary staff does not use any protective dressings except gloves and masks.

\section{Conflict of interest:}

"The authors declare no conflict of interest whatsoever arising out of the publication of this manuscript."

\section{Source of funding: Self}

Ethical Clearance:

This study was approved by the Ethical Review Committee of SKIMS Soura.

\section{REFERENCES}

[1]. Manual on hospital waste management, Yashpal Sharma 2001 edition, topic 4 page 1-5, book published by hospital administration GMC JAMMU.

[2]. Romea, S., Alkiza, M.E., Ramon, J.M., Oromi, J., 1995. Risk of occupational transmission of HIV infection among healthcare workers, study in a Spanish hospital. Eur. J. Epidemiol. 11, 225-229.

[3]. Indian Standards 'Solid Wastes-Hospitals-Guidelines for Management: IS

[4]. 12625:1989. Bureau of Indian Standards, New Delhi.

[5]. Basu R.N. Issues involved in Hospital Waste Management : an experience from a large teaching Institution, Journal of Academy of hospital Administration. July 1995, Jan. 1996 7(2), *(1) ; 79- 83.

[6]. Mark Taitz. Advanced Hospital Management, 1993;1:301-302.

[7]. Hospital Waste Management-A holistic approach. Anand R.C., S. Satpathy 1998 edition, Book published by Department of Hospital administration, AIIMS, New Delhi.

[8]. Centre for disease control, National institute of health. in: Richardson J H, Berkley W E, eds. Biosafety in microbiological and biomedical laboratories. Washington, D C: US Department of health and human services;1988. HHS Publication No. 88-8395.

[9]. U.S. Department of labour. Occupational Safety and Health Administration. Occupational exposure to blood borne pathogens: final rule, 56(235):64003-64182 (codified as Title 29, Code of Federal Regulation. SECTION 1910-1030. Bloodborne Pathogens). Federal Register 1991.

[10]. U.S. Environment Protection Agency. Standards for the tracking and management of medical waste. Interim final rule and request for comments, 54(56); 12325-12395 (codified as title 40, Code of Federal Regulations, part 259, Standards for and Management of Medical Waste), Federal register 1988;54.

[11]. Hansen L. Hansen A: Incineration of hospital waste. Hospital Abstracts HMSO, London 17 (4): 1977.

[12]. Judith G Gordon , Peter A Reinhardt, Gerald A Denys, Carla J Advarado. "Hospital Epidemiology and infectious on Control", edited by C. Glen Mayghall. Lippincot Williams and Wilkins, Philadephia. Medical Waste Management. 199;13871397.

[13]. Reinharat PA. Gordon JG Infectious and medical waste management. Chelas: Lewis Publisher, 1991.

[14]. Garner JS. The Hospital Infectious Control Practices advisory Committee; Guidelines for Isolation precautions in hospital. Infect Control Hospital Epidermal 1996;17;53-80

[15]. Urban Solid waste Management in India. Constitution of a high power committee. OM No. 4(6)/94- Ministry of Health and Family welfare Planning Commission Government of India October 1994.

[16]. Sarma RK, Mathur SK Management of Hospital Waste; Journal of Academy of Hospital Administration 1989;1(2):55-7.

[17]. Singh IB, Sarma RK. "Hospital waste system and technology". Journal of Academy of Hospital Administration 1997;8(2):33-39.

[18]. Guidelines for Management of Hospital waste and Standards for incinerator (1996) issued by Central Pollution Control Board.

[19]. Bransons M, Hazard of Sharps Disposal, British Journal of Nursing 1995;4(4):193-5. 